\title{
Establishing the safeness of gluten-free nourishment for laboratory animals
}

\author{
Yu.V. Ushakova ${ }^{1}$, G.E. Rysmukhambetova ${ }^{1}, I . V$. Ziruk $^{1, *}$, V.V. Frolov ${ }^{2}$, and K.A. \\ Grandonyan ${ }^{2}$ \\ ${ }^{1}$ Saratov State Vavilov Agrarian University, Saratov, Russia \\ ${ }^{2}$ Social and Economic Institute of Yuri Gagarin State Technical University of Saratov, Saratov, \\ Russia
}

\begin{abstract}
The experiment was carried out on lab rats which had been given the gluten free nutriment in the conditions of the veterinary clinic of «Saratov State Vavilov Agrarian University». During the research, the morphological and biochemical blood analysis' results were studied. Laboratory rats' condition was under daily clinical monitoring as well as their weight. According to the data collected, no external signs of intoxication and death of the rats had been found during the experiment. All rats were active. The concentration of hemoglobin in the experimental group has increased by $14.33 \mathrm{~g}$ per liter compared to the control group. Therefore, the use of gluten-free nourishment for animals does not have a negative effect on the homeostasis of the organism, which implies the safeness of a gluten-free diet.
\end{abstract}

\section{Introduction}

The range of gluten-free products is very inconsiderable in the modern world, because of that the variety of foods made without gluten strictly depends on import and usually it's limited by pasta and confectionery while the range of bakery products is minimal. $[1,6,11$, 13]. In this regard, research, on the development of a various gluten-free flour confectionery of the highest quality with improved nutritional value and microbiological firmness, which can be produced by discrete manufacturing, can be considered relevant. [4, $7,8,9,10]$. The clinical studies were needed to determine the effect of a gluten-free product on the body laboratory animals which could later be used as a confirmation of the safety of the developed products.

\section{Materials and Methods}

Animal materials and study design

The purpose of this research was to determine the effect of gluten-free products on laboratory animals to establish the safety of a gluten-free nutrition.

\footnotetext{
* Corresponding author: iziruk@yandex.ru
} 
Experimental studies on laboratory animals were performed in accordance with Federal law of 01.01.1997 "On the protection of animals from cruel treatment" and the provisions of the European Convention for the Protection of Vertebrate Animals of 18.03.1986, Strasbourg. The experiment was carried out in the conditions of the veterinary clinic of «Saratov State Vavilov Agrarian University» on laboratory animals - rats. The safety of gluten-free products on the overall homeostasis of the body of laboratory animals that received gluten-free cupcakes was established during the research. There were 10 male clinically healthy laboratory rats with a live weight of 175-180 g., which were studied under experimental conditions. The studied animals were kept in accordance with generally accepted techniques. [2, 5, 12]. Rats had been kept in quarantine for 21 day before they were used in the trial. Then they were divided in two groups 5 animals in each. The first one was called control group. The second was the experimental group. Animals of the control group were fed according to the accepted formula of complete compound feeds for rats in short-term experiments. The experimental group's rats were fed with grains of corn, rice and gluten-free cupcakes that had been developed at the faculty. (tbl. 1).

Table 1. Feeding ration of the experimental rats, \%

\begin{tabular}{|l|c|c|}
\hline \multicolumn{1}{|c|}{ Ingredient } & Control group & Experimental group \\
\hline Corn & - & 27.3 \\
\hline Rice & - & 27.4 \\
\hline Barley & 40.0 & - \\
\hline Wheat & 42.6 & - \\
\hline Fodder Yeast & 6.0 & 6.0 \\
\hline Meat and bone meal & 3.0 & 3.0 \\
\hline Bone meal & 1.2 & 1.2 \\
\hline Grass meal & 4.0 & 4.0 \\
\hline Chalk & 1.7 & 1.7 \\
\hline Table salt & 0.5 & 0.5 \\
\hline Premix & 1.0 & 1.0 \\
\hline Gluten-free cupcakes & - & 27.9 \\
\hline
\end{tabular}

On the $30^{\text {th }}$ day of the experiment euthanasia had been performed under anesthesia (Isoflurane) by translocation of the cervical vertebrae after which the morphological examination of internal organs and blood was conducted. All the blood tests were conducted in the Center for collective use of equipment based in «Saratov State Vavilov Agrarian University». The blood had been taken from the tail vein and then biochemical analyzer "BioChem SA» was used to analyze it. In order to confirm the validity of the biochemical analyzer's result we used control serum for biochemical studies according to Technical Conditions (TC) 9398-022-09807247-2009, LLC «HOSPITEX DIAGNOSTICS». The analysis of the morphological composition of peripheral blood was performed on a hematological analyzer MicroCC 20 vet[2].

Statistical analysis. The results were processed using the Microsoft Excel 2010 software application, as well as the statistical data analysis package StatPlus 2009.

\section{Results}

The animals were weighed and their clinical examination was carried out on a daily basis. There were no changes in a general state of the body: no deviations in behavior had been found, violations of motor activity or appetite had not been detected. Both groups did not have any signs of intoxication during the entire experiment. The animals were active, their 
reaction to external stimuli was not disturbed. Body temperature remained within the physiological values, according to their age characteristics. Both the control and experimental groups did not have any death during the experiment.

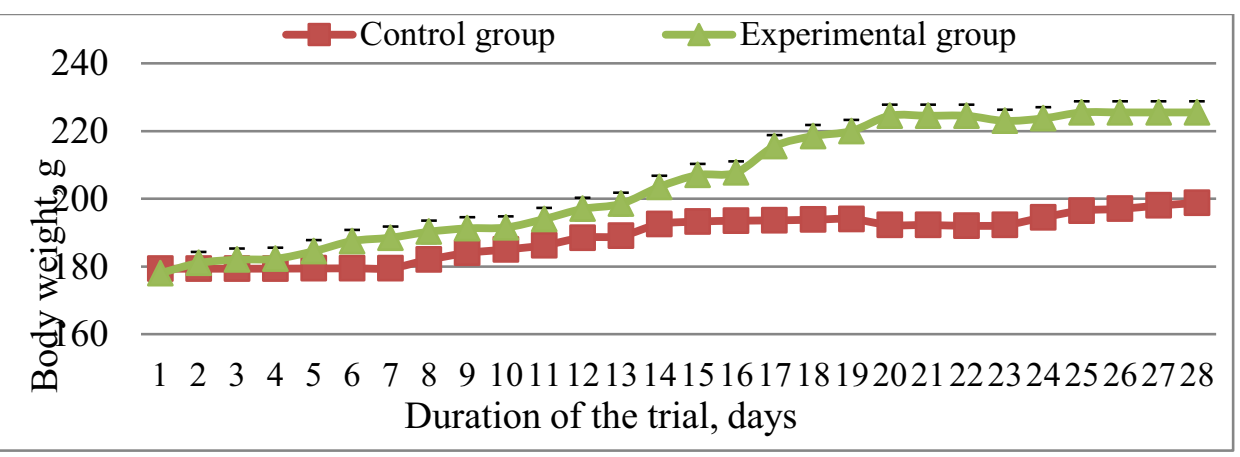

Fig. 1. The change of the live weight of laboratory rats during feeding period

Based on the data we've acquired and presented in Figure 1 we've noticed the change in the weight of laboratory rats. It increased by $4 \mathrm{~g}$ in the experimental group and by $6 \mathrm{~g}$ in the control group. The experimental group had a tangible increase in a speed at which rats gained weight which began on the $12^{\text {th }}$ day by $15 \mathrm{~g}$. The control group at that day had an increase of $10 \mathrm{~g}$ and as a result the speed at which weight increase was different as well as final result. The weight gain over the entire period of the experiment in the experimental group was $45.3 \mathrm{~g}$, in the control group $-7 \mathrm{~g}$.

The results of experiments on the study of morphological and biochemical indices of the blood of rats of control and experimental group are represented in Table 2.

Table 2. Morphological indices of rat blood

\begin{tabular}{|l|c|c|c|c|c|}
\hline \multirow{2}{*}{ Index name } & \multirow{2}{*}{$\begin{array}{c}\text { Unit of } \\
\text { measure }\end{array}$} & \multicolumn{2}{|c|}{$1^{\text {st }}$ day } & \multicolumn{2}{c|}{$30^{\text {th }}$ day } \\
\cline { 3 - 6 } & & Control group & $\begin{array}{c}\text { Experimental } \\
\text { group }\end{array}$ & Control group & $\begin{array}{c}\text { Experimental } \\
\text { group }\end{array}$ \\
\hline Red Blood Cell (RBC) & $10^{12} / \mathrm{L}$ & $7.96 \pm 0.01$ & $7.68 \pm 0.02$ & $8.84 \pm 0.07$ & $9.41 \pm 0.04$ \\
\hline Hematocrit (HCT) & $\%$ & $44.28 \pm 0.05$ & $45.46 \pm 0.03$ & $51.37 \pm 0.06$ & $52.01 \pm 0.05$ \\
\hline Hemoglobin (HGB) & $\mathrm{g} / \mathrm{L}$ & $148.11 \pm 0.05$ & $150.18 \pm 0.08$ & $159.21 \pm 0.04$ & $164.51 \pm 0.03^{*}$ \\
\hline $\begin{array}{l}\text { Mean Corpuscular } \\
\text { Hemoglobin } \\
\text { Concentration (MCHC) }\end{array}$ & $\mathrm{g} / \mathrm{L}$ & $327.05 \pm 0.04$ & $336.07 \pm 0.03^{*}$ & $337.03 \pm 0.05$ & $338.02 \pm 0.04$ \\
\hline $\begin{array}{l}\text { Red Cell Distribution } \\
\text { Width (RDW) }\end{array}$ & $\%$ & $16.30 \pm 0.06$ & $16.90 \pm 0.02$ & $16.50 \pm 0.08$ & $16.90 \pm 0.03$ \\
\hline $\begin{array}{l}\text { Mean Corpuscular } \\
\text { Hemoglobin (MCH) }\end{array}$ & $\mathrm{pg}$ & $16.50 \pm 0.05$ & $16.90 \pm 0.04$ & $16.70 \pm 0.07$ & $16.90 \pm 0.08$ \\
\hline $\begin{array}{l}\text { Mean Corpuscular } \\
\text { Volume (MCV) }\end{array}$ & $\mathrm{fL}$ & $49.00 \pm 0.03$ & $50.00 \pm 0.02$ & $48.00 \pm 0.09$ & $49.00 \pm 0.05$ \\
\hline $\begin{array}{l}\text { White Blood Cell } \\
\text { (WBC) }\end{array}$ & $10^{9} / \mathrm{L}$ & $8.92 \pm 0.02$ & $8.11 \pm 0.01$ & $8.10 \pm 0.05$ & $8.88 \pm 0.08$ \\
\hline Granulocytes & $\%$ & $22.70 \pm 0.06$ & $29.10 \pm 0.05 *$ & $23.90 \pm 0.08$ & $29.30 \pm 0.03 *$ \\
\hline Lymphocytes & $\%$ & $65.60 \pm 0.05$ & $68.90 \pm 0.08$ & $73.90 \pm 0.07$ & $76.90 \pm 0.04 *$ \\
\hline Monocytes & $\%$ & $1.70 \pm 0.06$ & $2.00 \pm 0.09$ & $2.10 \pm 0.07$ & $3.80 \pm 0.08^{*}$ \\
\hline Colour index & & $1.50 \pm 0.08$ & $1.40 \pm 0.01$ & $1.40 \pm 0.05$ & $1.50 \pm 0.02$ \\
\hline Platelet Count (PLT) & $10^{9} / \mathrm{L}$ & $687.01 \pm 0.07$ & $674.03 \pm 0.09$ & $695.02 \pm 0.05$ & $699.05 \pm 0.03^{*}$ \\
\hline $\begin{array}{l}\text { Mean Platelet Volume } \\
\text { (MPV) }\end{array}$ & $\mathrm{fL}$ & $7.80 \pm 0.07$ & $8.00 \pm 0.07$ & $7.80 \pm 0.08$ & $8.30 \pm 0.02$ \\
\hline $\begin{array}{l}\text { Platelet Distribution } \\
\text { Width (PDW) }\end{array}$ & & $35.00 \pm 0.02$ & $35.20 \pm 0.09$ & $34.60 \pm 0.07$ & $35.40 \pm 0.06$ \\
\hline Procalcitonin (PCT) & $\%$ & $0.54 \pm 0.09$ & $0.66 \pm 0.01$ & $0.51 \pm 0.08$ & $0.69 \pm 0.06$ \\
\hline
\end{tabular}

Note: $* \mathrm{P} \leq 0.05$ 
Morphological blood parameters of laboratory animals at the beginning of the experiment in all groups studied by us were within the age and physiological norm.

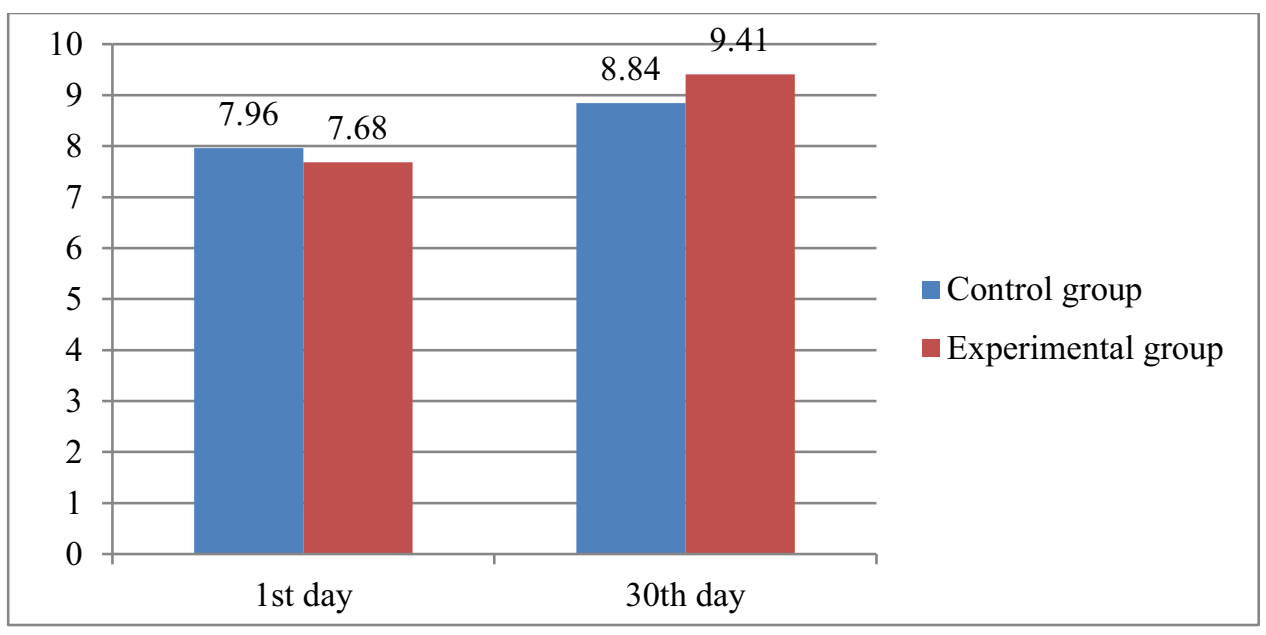

Fig. 2. The number of $\mathrm{RBC}$ in rats of the studied groups, $\mathrm{x} 10^{12} / \mathrm{L}$

The concentration of red blood cells in animals at the beginning of the experiment was at a relatively stable level, averaging $7.82 * 10^{12} / 1$ (fig. 2 ). On the $30^{\text {th }}$ day of the experiment the studied indicator in the control group was $8.84 \pm 0.07 * 10^{12} / 1$, while in the experimental group - $9.41 \pm 0.02 * 10^{12} / 1$. Red blood cells increased by $0.57 * 10^{12} / 1$ in the experimental group in comparison with the control. At the same time it should be noted, that the number of RBC through the trial did not go beyond the reference values of this type of rats.

The results of the blood test show that RDW, HCT, MCHC and MCV were at the same level throughout the experiment, within the limits of their physiological and age norms. Moreover, the experimental group saw the increase in HCT from $45.46 \pm 0.03$ to $52.1 \pm 0.05 \%$, and the average hemoglobin concentration in 1 red blood cell increased from $336.07 \pm 0.03$ to $338.02 \pm 0.04 \mathrm{~g} / 1$. The average size of $\mathrm{RBC}$ allowed us to characterize anemia more accurately, as well as determine the size of red blood cells in the blood. Gluten-free food had had a positive effect on morphological indices of blood, helping to maintain overall homeostasis in animals and, therefore, confirmed the biological safety of the studied supply.

The level of HGB (fig.3) increased in the control group by $11.10 \mathrm{~g} / 1$ and in the experimental group by $14.33 \mathrm{~g} / 1$, therefore, metabolic processes were somewhat more intense in the experimental group. 


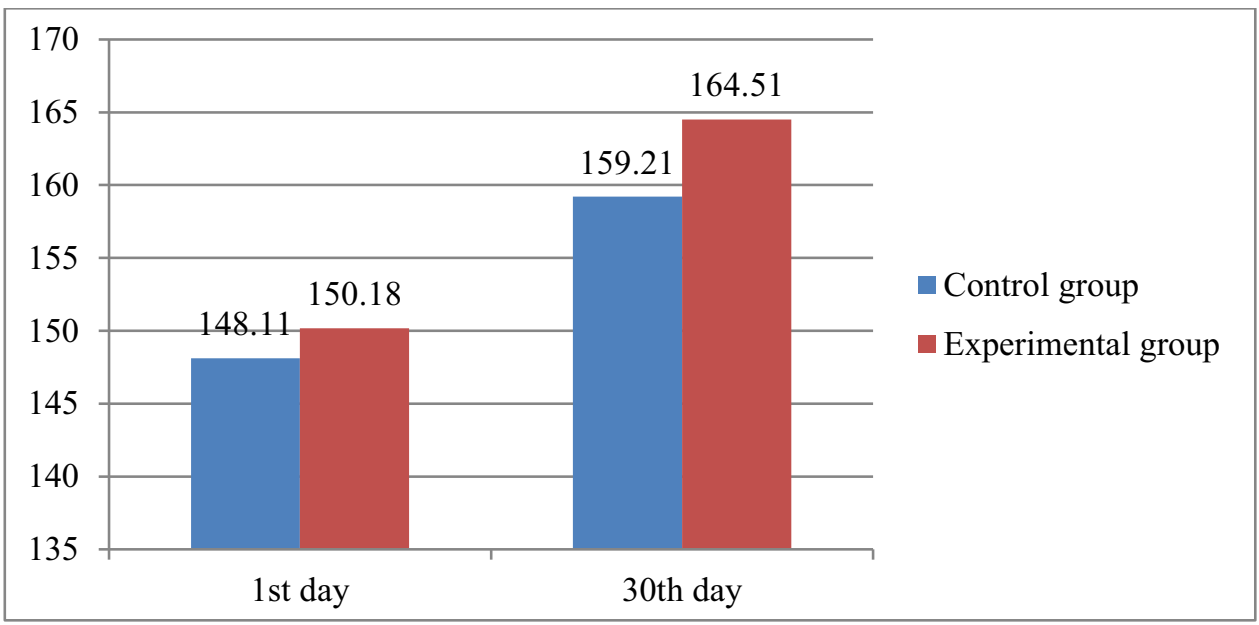

Fig. 3. The level of hemoglobin in rats of the studied groups, $g / \mathrm{L}$

The control group had an increased amount of WBC on the 30th day of the experiment averaged $8.10 * 109 / 1$, in turn, in rats of the experimental group, the content of white blood cells was $8.88 * 109 / 1$, that results were within the acceptable parameters. The analysis of the content of white blood cells indicates that no inflammatory processes were observed in the body of the studied animals, on the contrary, the rats of the experimental group had greater immune protective properties than the control analogues, indicating the biological safety of using gluten-free nutrition.

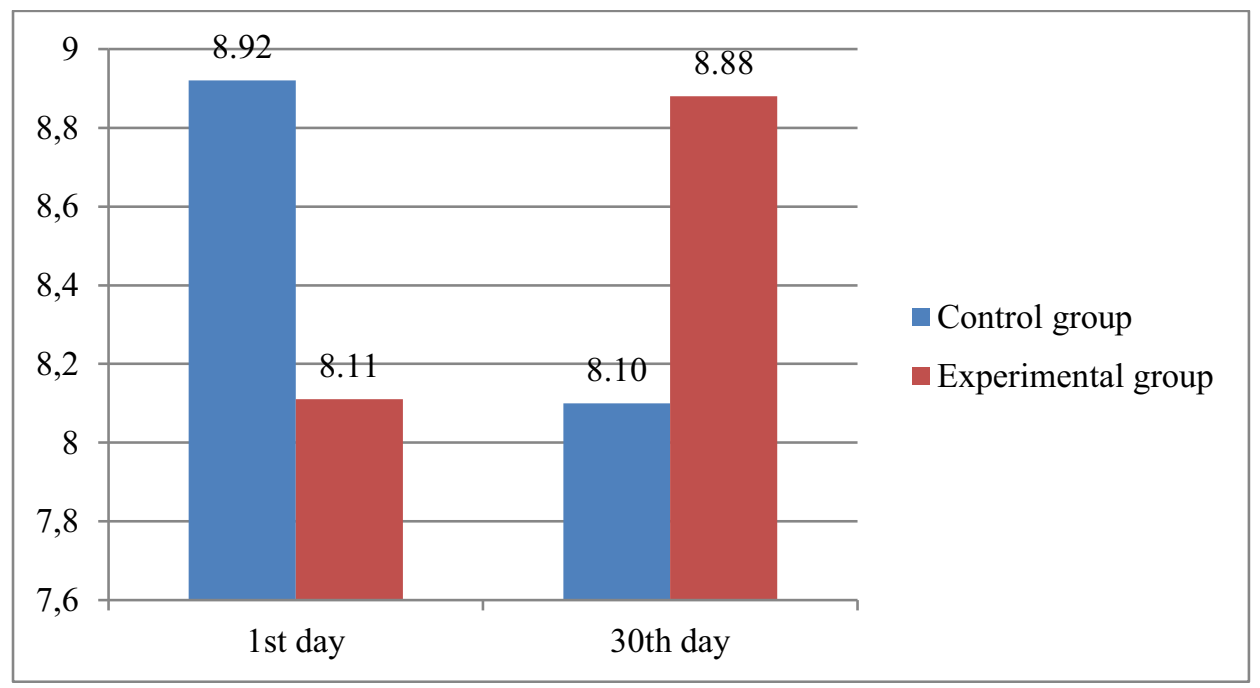

Fig. 4. The number of $\mathrm{WBC}$ in the blood of rats of the studied groups, $10^{9} / \mathrm{L}$

Platelets are elements of the blood responsible for clotting. A complete blood count can detect a decrease in platelets as well as prevent bleeding. [2, 3]. The experimental group saw an increase in the number of platelets by $25.0 \pm 0.01 * 10^{9} / 1$ during the experiment while the control group had a rise of $8.01 \pm 0.01 * 10^{9} / 1$. The data obtained about the rats was within the limits of their physiological norm, acceptable at their age.

As the result of hematological studies, we found out that the volume of RBC, WBC, PLT, Monocytes, HGB and HCT of the studied animals were all within the physiological norm and the animals were clinically healthy. 
Table 3. Biochemical analysis of blood counts of experimental rats

\begin{tabular}{|c|c|c|c|c|c|}
\hline \multirow{2}{*}{$\begin{array}{c}\text { Index } \\
\text { measure }\end{array}$} & \multirow{2}{*}{\begin{tabular}{c} 
Unit of \\
\cline { 3 - 6 }
\end{tabular}} & Control group & $\begin{array}{c}\text { Experimental } \\
\text { group }\end{array}$ & Control group & $\begin{array}{c}\text { Experimental } \\
\text { group }\end{array}$ \\
\hline Total protein & $\mathrm{g} / \mathrm{L}$ & $71.50 \pm 3.45$ & $76.50 \pm 4.01$ & $84.40 \pm 3.12$ & $88.50 \pm 3.96^{*}$ \\
\hline Albumins & $\mathrm{g} / \mathrm{L}$ & $23.70 \pm 1.56$ & $28.10 \pm 2.09$ & $32.80 \pm 1.94$ & $35.10 \pm 2.12^{*}$ \\
\hline Globulins & $\mathrm{g} / \mathrm{L}$ & $33.74 \pm 2.31$ & $38.20 \pm 2.49^{*}$ & $43.10 \pm 3.04$ & $45.70 \pm 2.95^{*}$ \\
\hline $\begin{array}{c}\text { Alanine } \\
\text { transaminase } \\
\text { (ALT) }\end{array}$ & $\mathrm{IU} / \mathrm{L}$ & $60.90 \pm 4.12$ & $59.80 \pm 4.18$ & $76.90 \pm 5.28$ & $77.50 \pm 4.92$ \\
\hline $\begin{array}{c}\text { Aspartate } \\
\text { aminotransferase }\end{array}$ & $\mathrm{IU} / \mathrm{L}$ & $152.40 \pm 9.76$ & $141.00 \pm 15.81$ & $182.20 \pm 21.08$ & $185.80 \pm 18.39^{*}$ \\
(AST) & & & & & \\
\hline $\begin{array}{c}\text { Alkaline } \\
\text { phosphatase }\end{array}$ & $\mathrm{IU} / \mathrm{L}$ & $187.90 \pm 26.91$ & $182.40 \pm 21.86$ & $222.10 \pm 17.63$ & $223.20 \pm 27.01^{*}$ \\
\hline Carbamide & $\mathrm{mmol} / \mathrm{L}$ & $6.70 \pm 0.69$ & $6.60 \pm 1.32$ & $7.10 \pm 0.94$ & $7.20 \pm 1.18$ \\
\hline Creatinin & $\mathrm{mmol} / \mathrm{L}$ & $50.20 \pm 6.87$ & $41.30 \pm 5.73$ & $71.80 \pm 7.82$ & $68.60 \pm 7.13$ \\
\hline Glucose & $\mathrm{mmol} / \mathrm{L}$ & $5.70 \pm 0.97$ & $6.80 \pm 0.68$ & $7.50 \pm 0.34$ & $7.80 \pm 1.04$ \\
\hline
\end{tabular}

Note: ${ }^{*} \mathrm{P} \leq 0.05$

Total protein concentration in the blood serum (tbl 3.) is one of the main indicators that characterize animals' growth and serves as a basis in the body's formation of immunity [2, $4,5,9]$.

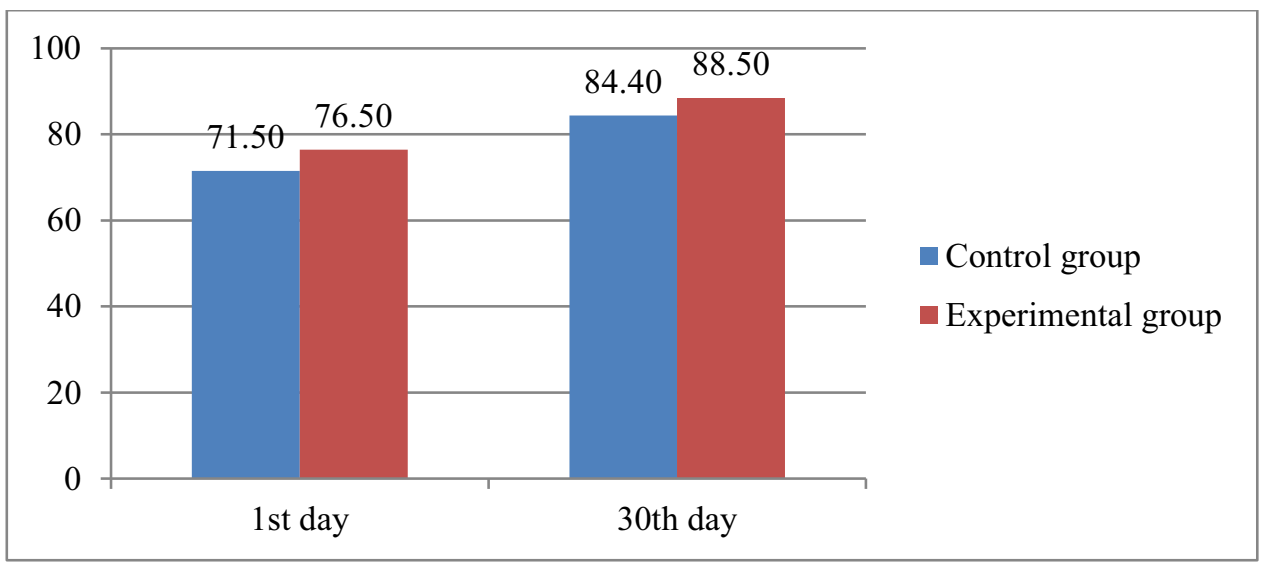

Fig. 5. Total protein's concentration in the blood serum, $g / \mathrm{L}$

At the beginning of the experiment, the amount of total protein had been $71.50 \mathrm{~g} / \mathrm{L}$ in the control group and $76.50 \mathrm{~g} / \mathrm{L}$ in the experimental, but by the end of the study, total protein content increased in the experimental group by $6 \%$ compared to the control group. The data obtained (fig.5) indicates that the rats of the experimental group had great protective properties against various diseases. 


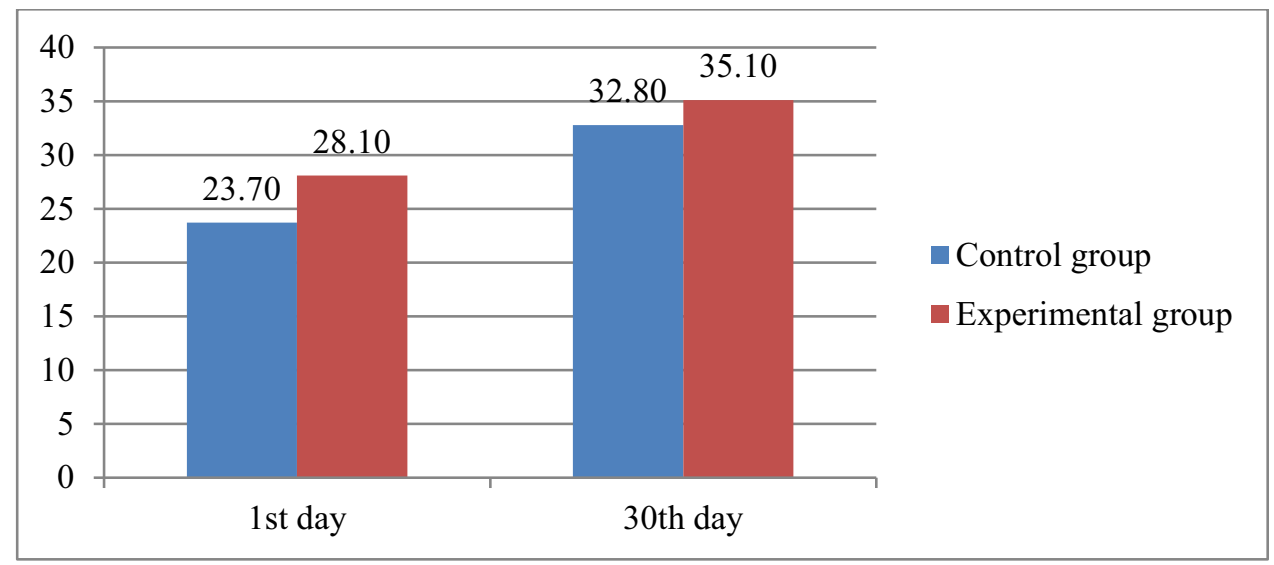

Fig. 6. Level of albumins in blood serum of rats, $g / L$

Albumins are responsible for transportation of a various blood substances, vitamins, fatsoluble steroids and drugs [2].

The difference between experimental and control groups in the albumin content was minimal, the former was just $4.4 \mathrm{~g} / \mathrm{L}$ ahead of the latter and such tendency continued throughout the experiment. As a result, the experimental group managed to keep its slight superiority (fig. 6).

Globulin provides the transportation to lipids; participates in the functioning of coagulation etc. It has just a similar pattern of superiority of the experimental group's rats over the control ones just as albumin. (fig.7)

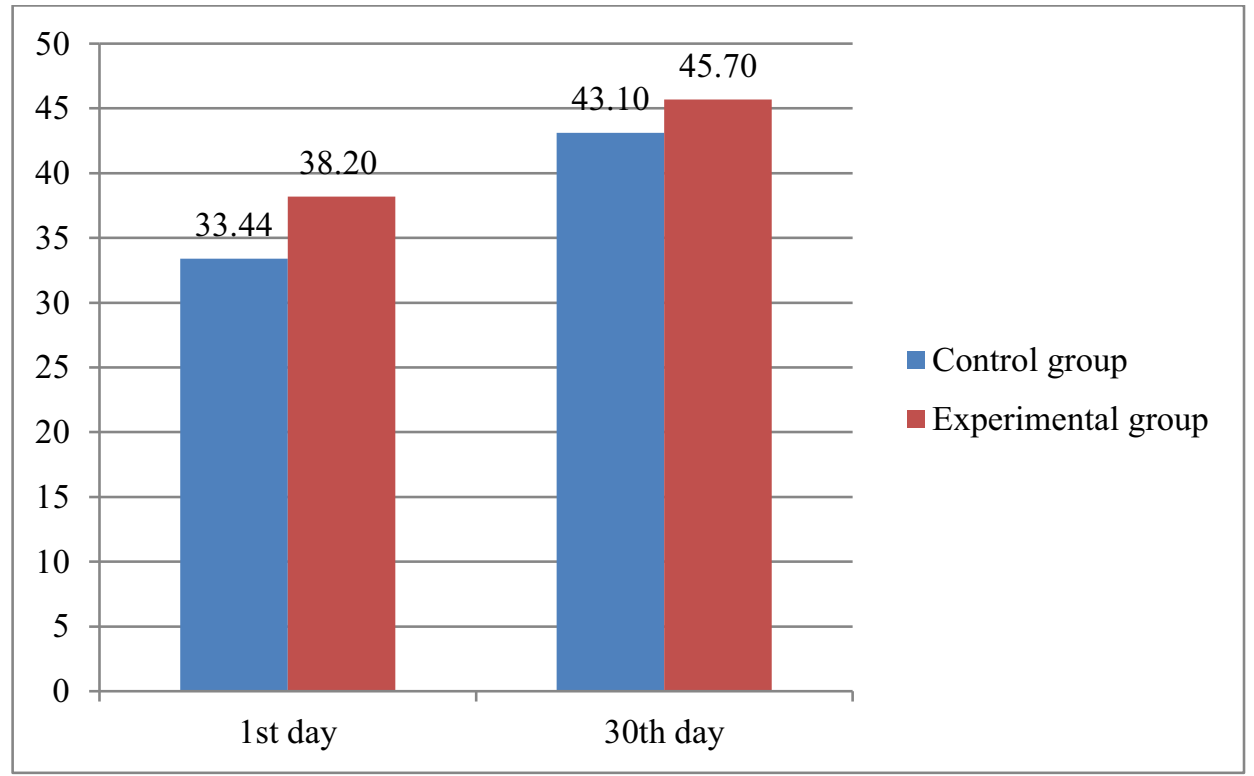

Fig. 7. Total level of globulins in a rat blood serum, $\mathrm{g} / \mathrm{L}$

Aspartate aminotransferase (AST) and alanine transaminase (ALT) are two endogenous enzymes that characterize the functional activity of the entire animal body. The results of the analysis indicators' activity showed us that the value of the parameters was stable throughout the experiment. Control group's AST and ALT results were $152.40 \mathrm{u} / \mathrm{l}$ and $60.90 \mathrm{u} / 1$ at the beginning of the experiment and $185.20 \mathrm{u} / 1$ and $77.50 \mathrm{u} / 1$ at the end. 
Carbamide has usually around $50 \%$ of the body's residual nitrogen. The primary obtained indicator of urea in the blood of animals was $6.70 \mathrm{mmol} / \mathrm{L}$ for control group and $6.60 \mathrm{mmol} / \mathrm{L}$ for experimental. As the experiment continued carbamide in the experimental group had started to change and reached $7.20 \mathrm{mmol} / \mathrm{L}$ at the end. Creatinine values were $50.20 \mathrm{mmol} / \mathrm{L}$ for control group and $41.30 \mathrm{mmol} / \mathrm{L}$ for experimental at the beginning of the trial. At the end of the experiment the indicator for the control and experimental groups was $71.80 \mathrm{mmol} / \mathrm{L}$ and $68.60 \mathrm{mmol} / \mathrm{L}$, respectively. The results of this test are within rats' physiological and age norm.

\section{Conclusion}

Gluten is a valuable vegetable protein. It can be found in wheat, rye, barley and oats. However, $1 \%$ of the world's population suffers from intolerance to this substance. This hereditary intolerance called celiac disease. It causes appetite decrease, loss of weight, slow growth, intestinal disorders, fatigue, pallor. The absorption of the vitamins worsens and leads to dry skin, hair loss and brittle nails.

On the one hand, gluten is found in large amounts in cereals such as wheat, rye, oats and barley. A very diverse amount of products contain hidden gluten, which was added there because of its ability to thicken and adhesiveness. For example, wheat starch is used as a way to thicken yoghurt or ice cream. Moreover, you even can find it in chocolate especially in milk chocolate. Gluten is almost pure protein, because its percentage value in 100 grams of dry product is $70 \%$. Companies use it as a basis for syrups and sauces such as ketchup, mayonnaise, soy sauce. It's often used as a protein supplement, for example, in the production of baby food and ready-made food.

On the other hand, buckwheat, rice, corn, soy and other cereals can be a safe alternative to people with celiac disease, because these are gluten-free products. In the connection with the above we've conducted research on a relevant topic- establishing the safeness of glutenfree nourishment to laboratory animals.

It has long been established that with age, different animals have an increase in body weight. In our studies, the increase in these indices is particularly clearly seen in rats that had gluten-free diet which, in our opinion, is the safest food for the studied animals.

In conclusion, our examination of rats' bodies reaction on the addition of gluten-free food lead to the results that show no negative side effects of such diet on morphological and biochemical indexes of blood tests. On the contrary it slightly increases the experimental group animal's immune response, improves the course of metabolic processes, while maintaining the body's full homeostasis. We believe that gluten-free products are biologically safe alternative for nourishment for laboratory animals.

\section{Availability of Data and Material}

Data can be made available by contacting the corresponding author.

\section{Conflict of Interest}

Authors declare no conflict of interest.

\section{Authors Contribution}

All authors contributed equally. 


\section{References}

1. R. Davydova, Confectionery and bakery production, 2, 50 (2013)

2. S.A. Lugovskaya, M.E. Postman, Hematological atlas, 214 (2001)

3. M.V. Pasko, E.A. Miller, I.V. Ziruk, G.E. Rysmukhambetova, In the collection: Materials of the conference on the results of research and production work of students in 2009, Student scientific and practical conference, 150 (2010)

4. I.V. Petrukhin, N.I. Petrukhin, Feeding domestic and decorative animals, Reference book. M, 156 (1992)

5. I.V. Fayustova, T.K. Kalenik, I.A. Suprunova, Materials of the VIII student international correspondence scientific and practical conference scientific community of students of the XXI century, Novosibirsk, 15 (2013)

6. Yu.V. Ushakova, G.E. Rysmukhambetova, Muffins with low gluten content, Patent of Russia No, 30, 2717005 (2020)

7. R.E.W. Halliwell, N.T. Gorman, Veterinary Clinical Immunology, 2, 38 (1998)

8. C. Mackay, B. Imhof, Immunology Today, 14, 99 (1993)

9. A.A. Nagdalyan, I.V. Ziruk, A.V. Egunova, Research Journal of Pharmaceutical, Biological and Chemical Sciences, 9(2), 1111 (2018)

10. G.V. Osipchuk, S.V. Povetkin, I.V. Ziruk, Pharmacophore, 10(2), 82 (2019)

11. V. V. Salautin, I. V. Ziruk, Pig breeding, 3, 32 (2008)

12. L.A. Tsurova, M.M. Musaev, A.P. Kushkhov, A.V. Misakov, V.S. Misakov, International transaction journal of engineering, management and applied sciences and technologies, 10(1),132 (2019)

13. L.I. Barybina, T.V. Voblikova, I.V. Ziruk, Journal of Hygienic Engineering and Design, 28, 81 (2019) 